\title{
Isolation and characterization of microsatellites in three overexploited penaeid shrimp species along the Brazilian coastline
}

\author{
Ana Karina de Francisco • A. P. Pinheiro • \\ T. B. Silva $\cdot$ P. M. Galetti Jr
}

Received: 11 March 2008/Accepted: 20 March 2008

(C) Springer Science+Business Media B.V. 2008

\begin{abstract}
Most Brazilian commercial species of penaeid shrimp are currently overexploited. Thirteen polymorphic microsatellite loci herein isolated and characterized in Farfantepenaeus brasiliensis, Rimapenaeus constrictus and Xiphopenaeus kroyeri could be very useful for population studies on these penaeid species and proved to be potentially functional in cross-amplification with other species of shrimp. These microsatellites may be very helpful tools for research programs aimed at the sustainable management and conservation of these important fishery resources.
\end{abstract}

Keywords Conservation - Polymorphic microsatellites · Farfantepenaeus brasiliensis - Rimapenaeus constrictus . Xiphopenaeus kroyeri

The exploitation of species of penaeid coastal shrimp in tropical regions is a very long-standing activity that has resulted in their current overexploitation (Costa et al. 2004). The impact of shrimp fisheries in these regions has become comparable to the most intensively exploited temperate shelf ecosystems in the world, thereby causing significant loss in spawning biomass and biodiversity (Pauly et al. 2002).

The pink shrimp Farfantepenaeus brasiliensis (Latreille 1817) and the seabob shrimp Xiphopenaeus kroyeri (Heller 1862), showing a wide geographic distribution quite similar along the Brazilian coast, have predominantly been

A. K. de Francisco - A. P. Pinheiro - T. B. Silva .

P. M. Galetti Jr ( $\square)$

Departamento de Genética e Evolução, Universidade Federal de

São Carlos, Via Washington Luiz km 235, Caixa Postal 676,

Sao Carlos, SP 13565-905, Brazil

e-mail: galettip@ufscar.br fished (Costa et al. 2004) and are currently considered overexploited (MMA 2004). Rimapenaeus constrictus (Stimpson 1874), although a non-commercial species due to its small body size (Castilho et al. 2007), can also undergone an extensive reduction in its population, being a typical by-catch species in commercial shrimp fisheries (Babler et al. 2000).

Microsatellites have been used to answer a wide variety of questions related to biological conservation (Taylor and Parkin 2007) and molecular analysis on Brazilian shrimp stocks should be very informative for their management and conservation (Gusmão et al. 2006). Thus far, microsatellites are unknown for $F$. brasiliensis, R. constrictus and $X$. kroyeri and 13 polymorphic loci are described in the present work.

A partially enriched genomic library of each target species was produced following Hamilton et al. (1999). DNA was isolated from muscle tissue through the method described by Aljanabi and Martinez (1997). After the digestion of this DNA with restriction enzymes, RsaI and BstUI (GE Healthcare), fragments with 200-800 bp were isolated using agarose gel, with the Wizard SV Gel and Polymerase Chain Reaction (PCR) Clean-Up System kit (Promega), and linked to adaptors (Hamilton et al. 1999). These products were enriched with eight biotinylated tetranucleotides, which were hybridizated to digested DNA and captured with magnetic beads (Streptavidin Magnesphere Paramagnetic Particles, Promega). Recovered fragments were cloned using the pGEM-T Easy kit (Promega). The clones containing inserts were sequenced in an automatic sequencer (ABI 377 and MegaBace 1000). The sequences obtained were analyzed using CID software (Freitas et al. 2008) to extract the vector sequence, find the sequences containing microsatellites and design the primers anchored in the flanking regions. 


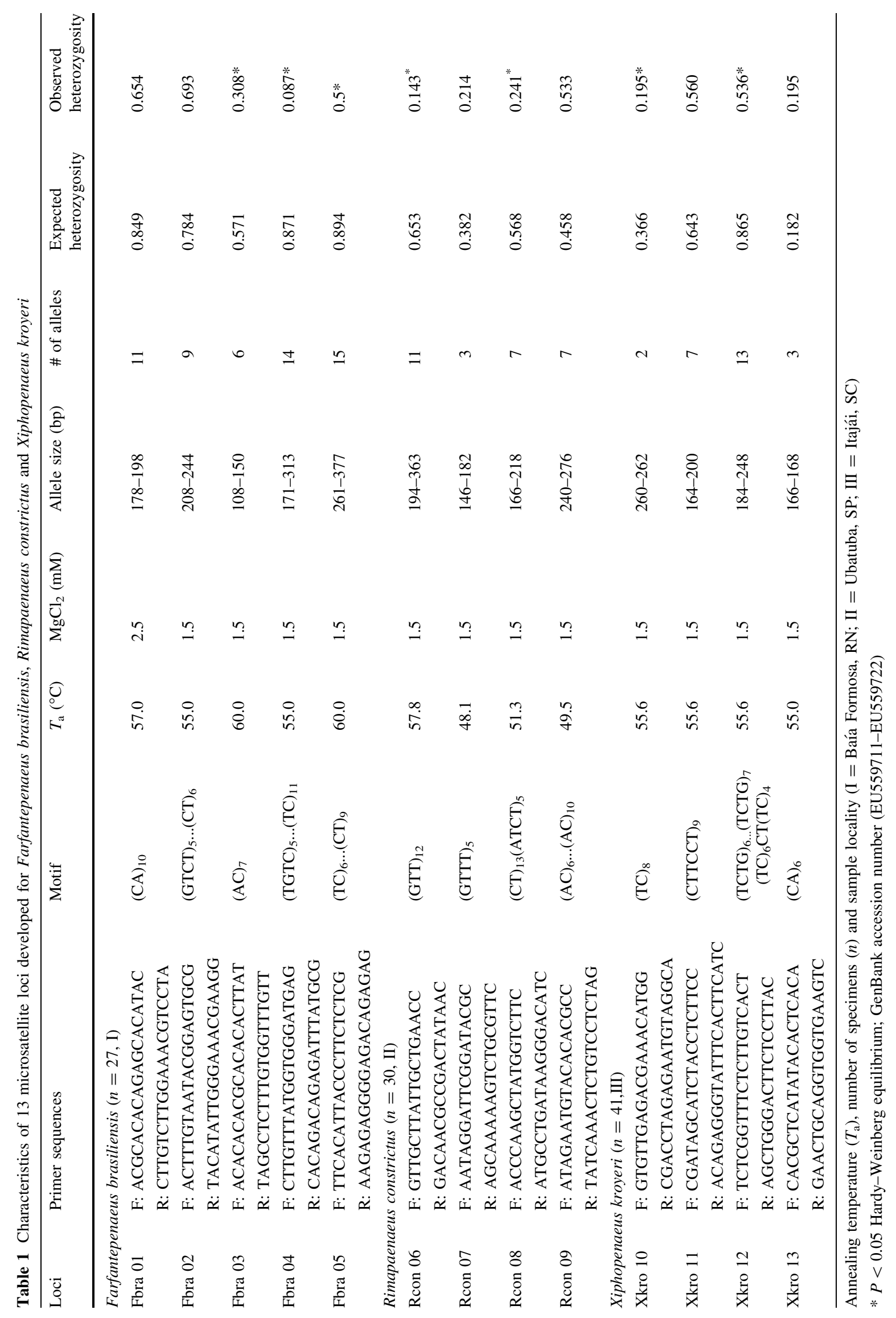


Table 2 Cross-species amplification in different penaeid shrimp

\begin{tabular}{|c|c|c|c|c|c|c|}
\hline Primer & F. brasiliensis & F. paulensis & L. schmitti & L. vannamei & R. constrictus & $X$. kroyeri \\
\hline Fbra 01 & + & + & + & - & + & + \\
\hline Fbra 02 & + & + & + & + & + & + \\
\hline Fbra 03 & + & + & + & + & + & + \\
\hline Fbra 04 & + & + & + & + & + & + \\
\hline Fbra 05 & + & + & - & - & + & - \\
\hline Rcon 06 & - & - & - & - & + & + \\
\hline Rcon 07 & + & - & - & + & + & + \\
\hline Rcon 08 & - & - & - & - & + & - \\
\hline Rcon 09 & - & + & - & - & + & - \\
\hline Xkro 10 & + & - & - & - & + & + \\
\hline Xkro 11 & - & - & - & - & - & + \\
\hline Xkro 12 & + & - & - & - & - & + \\
\hline Xkro 13 & - & - & + & - & + & + \\
\hline
\end{tabular}

The PCR optimum annealing temperature of each set of primers was achieved in a gradient Mastercycler thermocycler (Eppendorf). PCR conditioning was initial denaturation at $95^{\circ} \mathrm{C}$ for $5 \mathrm{~min}$ and 30 cycles of $94^{\circ} \mathrm{C}$ (30 s), $48-60^{\circ} \mathrm{C}$ (Table 1) (45 s) and $72^{\circ} \mathrm{C}(45 \mathrm{~s})$, followed by 8 cycles of $94^{\circ} \mathrm{C}(30 \mathrm{~s}), 53^{\circ} \mathrm{C}(45 \mathrm{~s}), 72^{\circ} \mathrm{C}(45 \mathrm{~s})$, with a final extension at $72^{\circ} \mathrm{C}$ for $10 \mathrm{~min}$. An M13-tail was endadded in the forward primer and an additional fluorescently-labeled M13 primer was used in the PCR (Schuelke 2000), as described elsewhere (Sanches and Galetti 2006). Each PCR reaction used $2 \mu \mathrm{l}$ of $1.25 \mathrm{mM}$ of dNTPs, $1.5 \mu \mathrm{l}$ of $10 \times$ amplification buffer $(200 \mathrm{mM}$ Tris- $\mathrm{HCl}, \mathrm{pH} 8.4$ and $500 \mathrm{mM} \mathrm{KCl}$; Invitrogen and/or Fermentas), 0.45$0.6 \mu \mathrm{l}$ of $50 \mathrm{mM}$ of $\mathrm{MgCl}_{2}, 1 \mu \mathrm{l}$ of $2 \mathrm{pmol} / \mu \mathrm{l}$ of the primer containing the complement tail to primer M13, $1 \mu \mathrm{l}$ of $8 \mathrm{pmol} / \mu \mathrm{l}$ of the primer without the tail, $1 \mu \mathrm{l}$ of $8 \mathrm{pmol} / \mu \mathrm{l}$ of fluorescently-labeled M13 primer (NED, 6-FAM or HEX), $0.1 \mu \mathrm{l}$ of $5 \mathrm{U} / \mu \mathrm{l}$ of Taq DNA Polymerase and $1 \mu \mathrm{l}$ of $5 \mathrm{ng} / \mu \mathrm{l}$ of DNA, completing a total volume of $15 \mu \mathrm{l}$. In X. kroyeri, some reactions used $7.5 \mu \mathrm{l}$ of GoTaq Colorless Master Mix (Promega) containing $1.5 \mathrm{mM}$ of $\mathrm{MgCl}_{2}$ and $200 \mu \mathrm{M}$ of each dNTP.

The PCR products were genotyped in a MegaBace 1000 automatic sequencer (Amersham Biosciences). The samples were analyzed using the GENETIC PROFILER software. Tests for deviation from the Hardy-Weinberg equilibrium and linkage disequilibrium were performed using the GENEPOP 3.4 program (Raymond and Rousset 1995) and corrected for multiple comparisons using the sequential Bonferroni procedure (Rice 1989). Significance values were estimated through the Markov chain method with 10,000 repetitions.

The results for each species are listed in Table 1. Linkage disequilibrium was not observed between loci. HWE deviations were probably related to null alleles, sample errors, preferential mating and inbreeding effects.
The number of alleles per locus ranged from two (Xkro 10) to 15 (Fbra 05) and the expected heterozygosity ranged from 0.182 (Xkro 13) to 0.894 (Fbra 05). Cross-species amplification was successful in several penaeid species using the same PCR conditions (Table 2).

The microsatellites described here could be very useful for population studies on the target species and could constitute a set of molecular tools that are very helpful to research programs aimed at the sustainable management and conservation of these commercial shrimp species. Brazil has about $13 \%$ of its coastline protected in conservation units and the importance of marine reserves in maintaining and enhancing the yield of adjacent fisheries is well known (Kelly et al. 2000). The knowledge on an intra-specific diversity level for a set of sympatric species could be used to orient the establishment of biological and genetically representative conservation units. In addition, these microsatellites proved to be informative for population studies on other penaeids, mostly native in the Brazilian coast.

Acknowledgements We are thankful to the Brazilian agencies Coordenação de Aperfeiçoamento de Pessoal de Nível Superior (CAPES) and Conselho Nacional de Desenvolvimento Científico e Tecnológico $(\mathrm{CNPq})$ for the financial support; Flávio Henrique da Silva for facilitating the use of the ABI 377 automatic sequencer; Adilson Fransozo and Rogério Costa for help in the sample collection and valuable information.

\section{References}

Aljanabi SM, Martinez I (1997) Universal and rapid salt-extraction of high quality genomic DNA for PCR-based techniques. Nucleic Acids Res 25:4692-4693

Babler SJM, Cyrus DP, Albaret JJ et al (2000) Effects of fishing on the structure and functioning of estuaries and nearshore ecosystems. ICES J Mar Sci 57:590-602

Castilho AL, Gavio MA, Costa RC et al (2007) Latitudinal variation in population structure and reproductive pattern of the endemic 
south american shrimp Artemesia longinaris (Decapoda: Penaeoidea). J Crustacean Biol 27:548-552

Costa RC, Fransozo A, Pinheiro AP (2004) Ecological distribution of the shrimp Pleoticus muelleri (Bate, 1888) (Decapoda, Penaeoidea) in southeastern Brazil. Hydrobiologia 529:195-203

Freitas PD, Martins DS, Galetti PM (2008) cid: a rapid and efficient bioinformatic tool for the detection of SSRs from genomic libraries. Mol Ecol Resour 8:107-108

Gusmão J, Lazoski C, Monteiro FA, Sole-Cava AM (2006) Cryptic species and population structuring of the Atlantic and Pacific seabob shrimp species, Xiphopenaeus kroyeri and Xiphopenaeus riveti. Mar Biol 149:491-502

Hamilton MB, Pincus EL, Di Fiori A et al (1999) Universal linker and ligation procedures for construction of genomic DNA libraries enriched for microsatellites. BioTechniques 27:500-507

Kelly S (2000) Spiny lobster, Jasus edwardsii, recovery in New Zealand marine reserves. Biol Conserv 92:359-369
Ministério do Meio Ambiente (2004) Instrução Normativa n 5. Diário Oficial da União, Rio de Janeiro

Pauly D, Christensen V, Guenette S et al (2002) Towards sustainability in world fisheries. Nature 418:689-695

Raymond M, Rousset F (1995) Genepop: population genetics software for exact tests and ecumenicism. J Hered 86:248-249

Rice WR (1989) Analysing tables of statistical tests. Evolution 43:223-225

Sanches A, Galetti PM Jr (2006) Microsatellite loci isolated in freshwater fish Brycon hilarii. Mol Ecol Notes 6:1045-1046

Schuelke M (2000) An economic method for the fluorescent labeling of PCR fragments. Nat Biotechnol 18:233-234

Taylor T, Parkin D (2007) Characterization of 13 microsatellite loci for the Moluccan Cockatoo, Cacatua moluccensis, and Cuban Amazon, Amazona leucocephala, and their conservation and utility in other parrot species (Psittaciformes). Conserv Genet 8:991-994 